\title{
ANALISIS DINAMIKA KELOMPOK TANI NELAYAN DI PESISIR KOTA BONTANG
}

\author{
Gusti Haqiqiansyah, Dayang Diah Fidhiani, Erwan Sulistianto \\ Fakultas Perikanan dan IImu Kelautan, Universitas Mulawarman \\ haqiqi87@yahoo.co.id
}

\begin{abstract}
ABSTRAK
Penelitian ini bertujuan untuk mengkaji tingkat dinamika kelompok tani nelayan di Pesisir Kota Bontang. Pengumpulan data dengan metode survei, yaitu melakukan pengamatan langsung di lapangan dan melakukan wawancara dengan responden. Responden yang diambil sebanyak 30 orang, yang tergabung dalam kelompok tani nelayan. Data yang terkumpul diolah, ditabulasi dan dianalisis secara diskriptif dengan menggunakan teknik skor. Hasil penelitian menunjukkan bahwa dari aspek dinamika kelompok, hasil analisis diperoleh nilai skor relatif tinggi, dengan rata-rata skor tercapai sebesar 89,85 (skor 75,1 97,5). Hal ini memberi indikasi bahwa kelompok tani nelayan relatif dinamis, yang berarti anggota kelompok menunjukkan kerjasama yang baik
\end{abstract}

Kata Kunci: Dinamika, Kelompok, Nelayan, Kota Bontang.

\section{ANALYSIS OF DYNAMIC GROUP OF FISHERIES AT COASTAL BONTANG CITY}

\begin{abstract}
This purpose of research is to assess the level of dynamics on farmer group of fishermen at Coastal in Bontang. Data collection was with survey methods, namely direct observation and interviews with respondents. Respondents were taken as many as 30 people who are members of farmer groups of fishermen. The data obtained were processed, tabulated and analyzed descriptively by using scoring techniques. The results showed that by the side of the aspect of group dynamics, the scores achieved was relatively high, with the average score achieved was 89.85 (scores range from 75.1 to 97.5). This indicates that groups of fishermen are relatively dynamic, which means that fellow members of farmers fishermen able to foster good cooperation.
\end{abstract}

Keywords: Dynamics, Group, Fishermen, Bontang City

\section{PENDAHULUAN}

Luas wilayah Kota Bontang yang mencapai $497.57 \mathrm{~km}^{2}$ didominasi oleh kawasan pesisir Kota Bontang ini telah memanfaatkan potensi sumberdaya perikanan dan kelautan untuk keberlangsungan hidupnya. Penghidupan utama masyarakat pesisir di Kota Bontang adalah berbasis penangkapan ikan dan budidaya ikan. Kegiatan ini telah dilakukan secara turun temurun.

Dinamika kehidupan masyarakat pesisir ini sangat dipengaruhi dan berkaitan erat dengan kepemilikan dan penguasaan aset-aset sosial dan ekonomi. yang meliputi aset sumberdaya alam, sumberdaya manusia. sumberdaya finansial, sumberdaya infrastruktur, dan sumberdaya sosial. Kualitas dan peran aktor-aktor atau pelaku kegiatan sangat strategis dan 


\section{\begin{tabular}{l|l} 
& Agriekonomika, ISSN 2301-9948 \\
April, 2016 & e ISSN 2407-6260
\end{tabular} \\ Volume 5, Nomor 1}

menentukan eksistensi nelayan atau pembudidaya ikan menjadi penentu keberhasilan ataupun kegagalan pembangunan di kawasan pesisir ini.

Pendekatan kelompok sampai saat ini masih digunakan dalam kegiatan penyuluhan. Pendekatan kelompok dipandang lebih efisien dan dapat menjadi media untuk terjadinya proses belajar dan berinteraksi dari para petani, sehingga diharapkan terjadi perubahan perilaku petani ke arah yang lebih baik atau berkualitas (Slamet, 2001). Hal ini dipertegas dari hasil penelitian Mugi (2011), menyatakan bahwa dinamika kelompok berpengaruh langsung terhadap kemandirian anggota kelompok tani dalam berusahatani. Kehadiran kelompok tani nelayan diharapkan mampu menjadi penggerak pembangunan masyarakat pesisir. Dengan berbagai kegiatan kelompok ini bisa menjadi kekuatan yang besar dan berpengaruh bagi kehidupan anggota khususnya maupun masyarakat pada umumnya. Urgensi dari upaya pemberdayaan masyarakat melalui kelompok adalah karena suatu kelompok secara lebih efektif dapat mewakili penerimaan, penolakan, maupun respon lain dari anggotanya terhadap kebijakan ataupun penerapan suatu program pembangunan. Di berbagai negara maju, pengalaman membuktikan bahwa kelompok-kelompok masyarakat telah berhasil mendorong pemerintah untuk melibatkan masyarakat dalam proses pengambilan keputusan, sehingga kebijakan yang diambil dapat mencerminkan aspirasi publik. Dengan demikian, kebijakan pemerintah dapat memperoleh dukungan secara luas. Peran kelompok-kelompok masyarakat, termasuk LSM telah mendorong proses pembangunan, dalam bentuk antara lain kajian dan pengembangan konsep atau teori, peningkatan kesadaran akan pentingnya partisipasi warga dalam pengambilan keputusan, advokasi untuk mereformasi kebijakan agar lebih kondusif terhadap partisipasi warga serta dalam mempraktekkan pendekatan pembangunan yang bersifat partisipatoris (Sumarto dan Hetifah, 2003). Dalam kaitan pembangunan masyarakat pesisir, konsep kegiatan kolektif dalam komunitas nelayan lebih menarik dibandingkan secara individu dan rumah tangga. Salah satu alasannya adalah adanya manfaat berupa terciptanya infrastruktur sosial dan kesepakatan bersama yang lebih baik dalam mengatasi benturan sosial ekonomi yang sering terjadi di wilayah pesisir. Berdasarkan uraian tersebut, maka perlu dilakukan kajian tentang dinamika kelompok tani nelayan, dengan tujuan penelitian yang ingin dicapai adalah mengkaji tingkat dinamika kelompok tani nelayan di pesisir Kota Bontang.

\section{METODE PENELITIAN}

\section{Tempat dan Waktu Penelitian}

Kegiatan penelitian dilaksanakan pada bulan Maret hingga Nopember 2015, dengan lokasi kegiatan di Kecamatan Bontang Utara Kota Bontang.

\section{Metode Pengambilan Sampel}

Sampel yang akan diambil dalam kegiatan penelitian ini adalah masyarakat nelayan di Kecamatan Bontang Utara Kota Bontang. Pengambilan sampel nelayan dilakukan secara bertahap, yaitu pada Tahap 1 ditentukan Kelompok Tani Nelayan yang akan dipilih sebagai sampel yaitu KTN yang seluruh anggotanya adalah nelayan. Pada tahap 2 dari kelompok yang terpilih diambil sampel secara acak sebanyak 30 orang.

\section{Metode Pengumpulan Data}

Mengumpulkan data primer dan data sekunder. Data primer merupakan data yang diperoleh dari sumber utama baik melalui pengamatan langsung (observasi) dari lapangan dan melakukan wawancara kepada responden dengan 
berpedoman pada daftar pertanyaan (kuesioner) yang telah disusun sesuai dengan tujuan penelitian. Adapun data sekunder diperlukan sebagai penunjang dan diperoleh dari Kantor Kelurahan. Dinas Kelautan dan Perikanan. serta laporan penelitian sejenis. Pengumpulan data sekunder dilakukan melalui studi kepustakaan serta sumber-sumber yang relevan dengan penelitian ini. Data sekunder meliputi profil wilayah, keragaan usaha masyarakat nelayan, dan data demografi.

\section{Metode Analisis Data}

Data yang terkumpul dari hasil observasi dan wawancara akan di tabulasi dan dianalisis secara deskriktif, yang akan diuraikan tentang karakteristik sosial ekonomi masyarakat nelayan, kegiatan-kegiatan kelompok tani nelayan, dan tingkat dinamika kelompok tani nelayan

Pengukuran untuk penilaian tingkat dinamika kelompok tani nelayan menggunakan kriteria yang disajikan pada Tabel 1 .

Tabel 1 Kriteria Penilaian Dinamika Kelompok

\begin{tabular}{lll}
\hline No. & Kriteria & \multicolumn{1}{c}{ Skor } \\
\hline 1 & Sangat Rendah & $30,0-52,5$ \\
2 & Rendah & $53,6-75,0$ \\
3 & Tinggi & $75,1-97,5$ \\
4 & Sangat Tinggi & $97,6-120,0$ \\
\hline
\end{tabular}

Sumber: Data Primer Diolah, 2015

\section{HASIL DAN PEMBAHASAN}

Deskripsi Wilayah Kota Bontang

Kota Bontang merupakan kota administratif, sebagai bagian dari wilayah Kabupaten Kutai, kemudian menjadi Daerah Otonom berdasarkan UndangUndang No. 47 Tahun 1999 tentang Pemekaran Provinsi dan Kabupaten. Sejak disahkannya Peraturan Daerah Kota Bontang No. 17 tahun 2002 tentang Pembentukan Organisasi Kecamatan Bontang Barat pada tanggal 16 Agustus 2002, kemudian Kota Bontang terbagi menjadi tiga kecamatan yaitu Kecamatan Bontang Utara, Kecamatan Bontang Selatan dan Kecamatan Bontang Barat.

Kota Bontang secara keseluruhan memiliki 15 kelurahan. Kecamatan Bontang Selatan terdiri atas enam kelurahan, Kecamatan Bontang Utara terdiri dari enam kelurahan dan Kecamatan Bontang Barat terdiri dari tiga kelurahan, untuk lebih jelasnya dapat dilihat pada Tabel 2. 
Tabel 2

Jumlah dan Nama Kelurahan Tiap Kecamatan

\begin{tabular}{|c|c|c|c|c|c|}
\hline \multirow{2}{*}{ No. } & \multirow{2}{*}{ Kecamatan } & \multicolumn{2}{|r|}{ Kelurahan } & \multicolumn{2}{|c|}{ Luas Daratan } \\
\hline & & Jumlah & Nama Kelurahan & $\mathrm{km}^{2}$ & $\%$ \\
\hline \multirow[t]{5}{*}{1.} & Bontang & 6 & Bontang Lestari & & \\
\hline & Selatan & & Satimpo & & \\
\hline & & & Berbas Pantai & 104,40 & 69,69 \\
\hline & & & Tanjung Laut & & \\
\hline & & & Tanjung Laut Indah & & \\
\hline \multirow[t]{5}{*}{2.} & Bontang & 6 & Bontang Kuala & & \\
\hline & Utara & & Bontang Baru & & \\
\hline & & & Api-Api & 26,20 & 17,48 \\
\hline & & & $\begin{array}{l}\text { Gunung Elai } \\
\text { Lok Tuan }\end{array}$ & & \\
\hline & & & Guntung & & \\
\hline \multirow[t]{2}{*}{3.} & Bontang & 3 & Kanaan & & \\
\hline & Barat & & Gunung Telihan & 19,20 & 12,83 \\
\hline
\end{tabular}

Sumber: Badan Pusat Statistik Bontang, 2014

\section{Kependudukan}

Tahun 2013 Kota Bontang memiliki jumlah penduduk 163.651 jiwa dengan kepadatan penduduk $1.092 \mathrm{jiwa} / \mathrm{Km}^{2}$. Kecamatan yang memiliki jumlah penduduk terbanyak adalah Bontang Utara sebesar 72.836 jiwa, kemudian Bontang Selatan sebesar 63.759 jiwa dan Kecamatan Bontang Barat sebesar 27.056 jiwa.

Tabel 3

Jumlah Penduduk Berdasarkan Jenis Kelamin Tahun 2013 di Kota Bontang

\begin{tabular}{llcccl}
\hline No. & Kecamatan & $\begin{array}{c}\text { Laki-laki } \\
\text { (Jiwa) }\end{array}$ & $\begin{array}{c}\text { Perempuan } \\
\text { (Jiwa) }\end{array}$ & $\begin{array}{c}\text { Jumlah } \\
\text { (Jiwa) }\end{array}$ & $\begin{array}{l}\text { Rasio Jenis } \\
\text { Kelamin }\end{array}$ \\
\hline 1. & Bontang Selatan & 33.209 & 30.554 & 63.759 & 110 \\
2. & Bontang Utara & 38.138 & 34.696 & 72.836 & 111 \\
3 & Bontang Barat & 14.250 & 12.804 & 27.056 & 112 \\
& Jumlah & 85.597 & 78.054 & 163.651 & 110 \\
\hline
\end{tabular}

Sumber: Badan Pusat Statistik Bontang, 2014

\section{Potensi Perikanan}

Potensi perikanan di Kota Bontang cukup potensial, karena masih tersedianya sumberdaya pendukung perikanan. Hutan mangrove yang dimiliki memiliki luas sebesar $1.115,5$ ha, gosong pulau seluas 940 ha, luas padang lamaun 741 ha, dan luas keseluuhan terumbu karang yang dimiliki 6.454 ha, serta area marikultur ikan dan rumput laut seluas 423 ha.

Usaha penangkapan ikan di laut merupakan usaha perikanan yang paling dominan dilakukan oleh masyarakat di daerah tersebut, selain itu juga tidak sedikit yang melakukan pembudidaya ikan maupun rumput laut. Hal tersebut dikarenakan selain luas areal usaha yang tidak terbatas juga karena jenis hasil tangkapan yang relatif beragam jumlahnya. Berdasarkan laporan statistik perikanan Dinas Perikanan, Kelautan dan Pertanian Kota Bontang, produksi 
perikanan tangkap sebanyak 8.385 ton dan perikanan budidaya sebesar 3.002 ton.

\section{Profil Responden}

Berdasarkan hasil wawancara dengan responden diketahui bahwa umur responden berkisar antara 22-60 tahun. Pada umumnya mereka masih aktif melakukan kegiatan penangkapan dan tergolong kelompok usia produktif. Untuk variabel pendidikan diketemukan bahwa sebagian besar responden sudah memperoleh pendidikan dari Sekolah Dasar (SD) hingga Sekolah Menengah Atas (SMA), yaitu $56,67 \%$ responden berpendidikan Sekolah Dasar (SD), $30,00 \%$ pendidikan SLTP, dan 13,33\% berpendidikan SLTA. Jumlah tanggungan berkisar dari 1 hingga 6 orang dalam satu rumah tangga nelayan. Tanggungan terbesar antara $1-2$ orang sebanyak $20,00 \%$, sedangkan yang tanggungan antara 3-4 orang sebanyak $46,67 \%$, dan tanggungan 5-6 orang sebanyak $33,33 \%$.

\section{Analisis Tingkat Dinamika Kelompok Tani Nelayan}

Dinamika merupakan suatu pola atau proses pertumbuhan. perubahan atau perkembangan dari suatu bidang tertentu, atau suatu sistem ikatan yang saling berhubungan dan saling mempengaruhi antara unsur yang satu dengan yang lain, karena adanya pertalian yang langsung diantara unsur-unsur tersebut. Artinya apabila salah satu unsur dari sebuah organ mengalami gangguan atau perubahan, maka akan membawa perubahan pula pada unsur-unsur lainnya. sehingga berakibat terjadinya perubahan pada sistem atau kelompok secara keseluruhan. Pengertian dinamika lebih menekan pada gerakan yang timbul dari dalam dirinya sendiri, artinya sumber gerakan berasal dari kelompok itu sendiri bukan dari kelompok luar. Dinamika kelompok dalam kajian ini dilakukan dengan pendekatan psiko-sosial, dengan unsur-unsur dinamika kelompok adalah tujuan, struktur, fungsi tugas. keefektifan kelompok, kesatuan dan kekompakan kelompok, suasana kelompok, ketaatan kelompok, dan maksud tersembunyi (Ibrahim dan Tarik, 2002)

Berdasarkan hasil kajian, diketahui tingkat dinamika kelompok tani nelayan tergolong tinggi, dengan rata-rata skor tercapai sebesar 89,85 (kisaran skor 75,1-97,5). Hal ini memberi indikasi bahwa hubungan sesama anggota kelompok berjalan cukup baik. Kelompok yang dinamis ini sangat diperlukan dalam pengembangan kemampuan kelompok. Hal ini sejalan dengan hasil penelitian Mugi (2011), menyatakan bahwa dinamika kelompok yang dinamis berpengaruh langsung terhadap kemandirian petani dalam berusaha. Menurut hasil penelitian Djoni dan Maulana (2009), dinamika kelompok yang tinggi karena kegiatan kelompok dilaksanakan berazaskan untuk petani, dari petani, dan oleh petani. Oleh karenanya dalam pelaksanaan harus mencerminkan ciri-ciri seperti kemitraan, kebersamaan, partisipasi, pengalaman nyata, keswadayaan, kesinambungan, manfaat, kesesuaian, keterpaduan, latihan, dan sarana belajar.

Kondisi demikian juga terjadi pada kelompok tani nelayan, dalam proses perencanaan kegiatan selalu dimusyawarahkan dan setiap anggota diajak untuk berperan aktif. Proses komunikasi yang baik terjadi sesama anggota, sehingga arus informasi dan kebutuhan anggota kelompok dapat diketahui. Dinamika kelompok tani nelayan yang relatif tinggi, dapat dimanfaatkan oleh seorang penyuluh perikanan sebagai modal dalam upaya memperkuat kedudukan kelompok, sehingga proses adopsi inovasi dapat berjalan lebih cepat. Sesuai 


\section{Agriekonomika, ISSN 2301-9948

hasil penelitian Wijayanti dan Ihsannudin (2013), menjelaskan bahwa mengintensifkan pemberdayaan kelompok nelayan yang ada misalnya semua anggota kelompok nelayan harus lebih aktif lagi dalam kegiatan apa saja yang berkaitan dengan hal yang berbasis perikanan dan kelautan merupakan salah satu strategi untuk penanggulangan kemiskinan masyarakat nelayan. Dengan kondisi kelompok yang dinamis tersebut maka peran dan fungsi kelompok tani nelayan harus dioptimalkan.

\section{Tingkat Dinamika Kelompok Berdasarkan Indikator Tujuan Kelompok}

Tujuan kelompok adalah sesuatu yang ingin dicapai oleh kelompok. Tujuan kelompok sebaiknya banyak yang sama dengan tujuan-tujuan individual anggota. Kegunaan tujuan dalam suatu kelompok adalah memberikan arahan pada kegiatan kelompok sehingga tujuan kelompok dapat dijadikan kriteria pengukur kemajuan.

Tingkat dinamika kelompok tani nelayan berdasar tujuan kelompok termasuk pada kriteria tinggi, dengan rata-rata skor tercapai sebesar 89. Ini memberi indikasi bahwa tujuan dari kelompok relatif sama dengan tujuan pribadi anggota. Para nelayan bergabung dalam kelompok dilandasi oleh kepentingan dan keinginan yang sama, untuk membangun dan memajukan kelompok sehingga kelompok tetap berjalan. Hal tersebut menjadi sangat penting dan strategis dalam upaya meningkatkan fungsi dan peran kelompok tani nelayan. Hal senada ditegaskan berdasarkan hasil kajian Hernanto dan Swastika (2009), menyatakan bahwa penguatan kelompok tani sebagai langkah awal peningkatan kesejahteraannya. Peranan dan fungsi kelompok tani akan semakin meningkat apabila dapat menumbuh kembangkan kekuatan-kekuatan yang dimiliki dalam kelompok itu sendiri, untuk menggerakan dan mendorong perilaku anggotanya ke arah pencapaian tujuan kelompok, sehingga kelompok tani tersebut berkembang menjadi lebih dinamis.

\section{Tingkat Dinamika Kelompok Berdasarkan Indikator Struktur Kelompok}

Struktur kelompok merupakan komponen kelompok yang mengatur interaksi dalam kelompok untuk mencapai tujuan. Setiap kelompok membentuk strukturnya sendiri secara unik. tidak perlu sama dengan struktur kelompok lain. Struktur kelompok merupakan pengubah yang menentukan efektif dan efisiensi tindaknya interaksi kelompok itu. Dalam struktur kelompok perlu pertimbangan: Kewenangan (aturan bagaimana keputusan kelompok akan diambil), sistem komunikasi (bagaimana penyampaian pesan dalam dan keluar kelompok dilakukan), aktivitas (dengan aktivitas apa tujuan kelompok tercapai), hak dan kewajiban (aturan tentang segala apa yang harus dilakukan oleh masing-masing anggota), besarnya kelompok, solidaritas kelompok, dan kesempurnaan pencapaian tujuan.

Struktur kelompok yang jelas sangat penting dalam proses pembangunan dan perkembangan kelompok. Berdasarkan hasil pengamatan dan diskusi diperoleh bahwa dalam kelompok tani nelayan telah terbentuk struktur kelompok yang jelas. Berdasarkan hasil analisis berdasarkan indikator struktur kelompok tergolong tinggi, dengan rata-rata skor tercapai sebesar 94, yang berada pada kisaran skor tinggi. Hal ini menunjukkan bahwa mayoritas anggota kelompok nelayan mengangap bahwa struktur kelompok yang terbentuk sudah jelas dan ada pembagian tugas dan tanggung jawab kepada setiap anggotanya. 


\section{Tingkat Dinamika Kelompok Berdasarkan Indikator Fungsi Tugas}

Fungsi tugas adalah segala sesuatu yang berhubungan dengan usaha memfasilitasi dan mengkordinasikan usaha-usaha kelompok yang menyangkut masalah-masalah bersama dan dalam rangka memecahkan masalah itu. Fungsi tugas dapat juga diartikan sebagai hal-hal yang harus dilakukan di dalam kelompok agar kelompok dapat mencapai tujuannya. Dalam fungsi tugas harus dapat dipenuhi beberapa hal, antara lain: Kepuasan karena sudah mencapai tujuan, mencari gagasan untuk keperluan kelompok, koordinasi untuk mencapai kesepakatan bersama, inisiasi dengan memotivasi semua anggota agar kegiatan kelompok berhasil diseminasi yakni menyebarkan informasi agar semua mengetahui dan terlibat serta menjelaskan segala sesuatu bila semua orang tidak mengerti. Pembinaan dan pengembangan kelompok adalah segala usaha menjaga kelompok agar tetap hidup. Usaha-usaha yang tergolong pembinaan dan pengembangan kelompok adalah partisipasi, fasilitas, aktifitas, koordinasi, komunikasi, penentuan standar, sosialisasi, dan mendapatkan anggota baru.

Berdasarkan hasil penelitian diketahui sebagian besar anggota kelompok menganggap fungsi tugas sudah berjalan baik, sesuai hasil analisis rata-rata skor tercapai sebesar 81,75 termasuk dalam tingkat tinggi. Ini memberi indikasi bahwa pengurus kelompok sudah mampu melaksanakan tugas dan fungsinya. Proses komunikasi yang lancar dan pembinaan kelompok yang rutin dari Pembina kelompok sangat menunjang anggota kelompok untuk dapat memaham tugas dan tanggung jawabnya.

\section{Tingkat Dinamika Kelompok Berdasarkan Indikator Keefektifan Kelompok}

Keefektifan kelompok pada dasarnya adalah kualitas kelompok dalam mencapai tujuan, bila dilihat dari sisi kuantitatif adalah jumlah tujuan yang sudah dicapai kelompok. Pada dasarnya keefektifan adalah hasil dari dinamika. namun keefektifan/ keberhasilan kelompok akan cenderung meningkatkan dinamika kelompok. Keefektifan kelompok dapat dilihat dari berbagai sudut yaitu: Dari hasil produktifitasnya. dari moral kelompok dan tingkat kepuasan anggotaanggotanya.

Keefektifan kelompok tani nelayan dalam hal ini bagaimana kelompok mempelajari informasi yang disampaikan pembimbing dan pengurus kelompok. Berdasarkan hasil analisis rata-rata skor tercapai sebesar 79,8 yang berada pada kategori tinggi. Anggota kelompok secara aktif mencari informasi baik kepada pembimbing dan pengurus kelompok, sehingga kelompok dapat melaksanakan tugas dengan maksimal dalam kelompok.

\section{Tingkat Dinamika Kelompok Berdasarkan Kesatuan dan Kekompakan Kelompok}

Kesatuan dan kekompakan kelompok adalah komitmen yang kuat dari seluruh anggota untuk mencapai tujuan. Kesatuan dan persatuan kelompok menjadi kekuatan bagi kelompok untuk mencapai tujuan dan mengatasi rintangan. Faktor-faktor yang mempengaruhi kesatuan dan kekompakan kelompok adalah kepemimpinan, keanggotaan, nilai tujuan kelompok, homogenitas, integrasi, kerja sama, dan besarnya kelompok.

Berdasarkan hasil analisis diketahui bahwa indikator kesatuan dan kekompakan kelompok termasuk pada kategori tinggi dengan rata-rata skor yang diperoleh sebesar 92,6. Hal ini mengindikasikan bahwa kesatuan dan kekompakan kelompok sudah terjalin dengan baik. Sifat kepemimpinan yang 


\section{Agriekonomika, ISSN 2301-9948

diterapkan ketua kelompok sangat memenuhi harapan anggota dikarenakan pemimpin dapat memberikan motivasi dan arahan yang baik kepada anggota. Kondisi demikian sangat mendukung menciptakan kondisi yang kondusif dalam kelompok. Tingkat kesadaran anggota kelompok juga sangat menunjang, karena adanya kesamaan persepsi yang tinggi, karena mereka bergabung dengan kelompok dengan tujuan agar dapat memperbaiki dan meningkatkan usahanya, pada akhirnya dapat meningkatkan kualitas hidupnya. Tujuan kelompok sudah sangat sesuai dengan harapan anggota, sehingga kelompok ini dijadikan sumber belajar dan kerjasama sesama nelayan. Hal ini dipertegas hasil penelitian Falo (2015), kekompakan kelompok menunjukkan keadaan atau kondisi dimana aktivitas anggota membangun semangat yang tinggi dan kesetiaan yang mendalam pada kelompok sehingga secara bersama-sama saling memberi nuansa hidup, menjadi diri sendiri dan kreatif. Kekompakan kelompok merupakan suatu kondisi dimana aktivitas anggota membangun semangat yang tinggi dan rasa kesetiaan yang mendalam pada kelompok secara bersama-sama, sehingga ikatan emosional antara anggota saling mengenal diri sendiri dan akan menimbulkan kekompakan yang kuat antara kelompok

\section{Tingkat Dinamika Kelompok Berdasarkan Indikator Suasana Kelompok}

Suasana kelompok adalah sikap mental dan perasaan-perasaan yang secara umum ada dalam kelompok. Suasana kelompok dapat disebut juga dengan moral kelompok yaitu suasana semangat dalam kelompok apakah bersemangat, tidak bersemangat, atau apatis. Fakor-faktor yang mempengaruhi suasana kelompok adalah ketegangan, keramahan, rasa persahabatan, kebebasan lingkungan fisik, dan tingkat demokrasi dalam kelompok.

Berdasarkan hasil analisis diketahui bahwa rata-rata skor tercapai 95,7, yang berada pada kisaran skor tinggi. Hal ini menunjukan bahwa suasana kelompok yang kondusif dapat meningkatkan dinamika kelompok. Kemampuan kelompok dalam menyelesaikan masalah selalu dengan baik dan hubungan antar sesama anggota sangat baik Hubungan kelompok dengan individu-individu sangat baik dilihat dari bagaimana kelompok ini saling merangkul dalam setiap permasalahan peribadi anggota, yang mengakibatkan para anggota betah dalam melakukan kegiatan dalam kelompok. Dilihat dari lingkungan fisik anggota mengatakan bahwa lingkungan mereka sangatlah baik sehingga kelompok ini tetap berjalan tanpa ada hambatan dari lingkungan sekitar.

\section{Tingkat Dinamika Kelompok Berdasarkan Indikator Ketaatan Kelompok}

Ketaatan kelompok adalah aturan atau norma yang telah disepakati, dapat diikuti dan dilaksanakan anggota secara konsisten. Indikator ketaatan kelompok menunjukkan bahwa nlai rata-rata skor adalah 91, berada pada kisaran skor tinggi. Hal ini mengindikasikan bahwa sebagian besar anggota mentaati peraturan yang ada di dalam kelompok. Anggota sangat taat dalam mengikuti setiap aturan-aturan yang telah ditentukan oleh kelompok, tanpa ada yang melanggar peraturan ataupun norma-norma yang ada. Anggota menyadari bahwa segala ketentuan / peraturan yang dibuat sudah disepakti secara bersama.

\section{Tingkat Dinamika Kelompok Berdasarkan Indikator Maksud Tersembunyi}

Maksud tersembunyi adalah program tugas atau tujuan yang tidak diketahui/disadari oeh para anggota kelompok sifatnya berada di bawah 
permukaan. Maksud tersembunyi bersifat saling mempengaruhi dan sama pentingnya dengan maksud/tujuan yang terbuka. Maksud terselubung ini penting artinya bagi kehidupan kelompok dan harus dipecahkan bersama. Kelompok dapat bekerja untuk maksud-maksud terselubung dan terbuka pada saat yang sama. Sumber maksud terselubung bisa dari anggota kelompok, pimpinan kelompok atau kelompok sendiri.

Dinamika kelompok dengan indikator maksud tersembunyi termasuk dalam kategori tinggi, hal ini dikarenakan sistem pembagian kerja yang ada dalam kelompok sebagian sudah sesuai dengan harapan awal. Bergabungnya dalam kegiatan kelompok selalu dilandasi pada kesepakatan yang telah ditentukan. Kondisi demikian tentunya sangat mendukung kekondusifan kelompok. Kegiatan pertemuan rutin sering dimanfaatkan pengurus kelompok untuk menyampaikan program-program baru didapat dari pembina kelompok. Suasana kelompok yang terbuka dan saling percaya, sangat memungkinkan dan memudahkan setiap orang untuk menyampaikan ide/gagasan baru demi kemajuan kelompok. Sikap saling menghargai dan selalu memutuskan setiap masalah secara bersama (musyawarah) menjadi faktor pengikat yang kuat sesama anggota kelompok tani nelayan.

\section{PENUTUP}

Berdasarkan hasil analisis dan pembahasan dapat diambil kesimpulan dari hasil penelitian adalah tingkat dinamika kelompok tani nelayan tergolong tinggi, dimana diperoleh rata-rata skor tercapai sebesar 89,85 (kisaran skor 75,1-97,5). Hal ini menunjukkan bahwa kelompok nelayan relatif dinamis, artinya sesama anggota kelompok mampu membina kerjasama yang baik, sedangkan berdasarkan unsur-unsur dinamika kelompok, yaitu tujuan kelompok (skor tercapai 89) kriteria tinggi, indikator struktur kelompok (skor 94) tergolong tinggi, unsur fungsi tugas (skor tercapai 81,75) kriteria tinggi, unsur keefektifan kelompok (skor tercapai 79,8 ) kategori tinggi,unsur kesatuan dan kekompakan kelompok (skor tercapai 92,6) kategori tinggi,unsur suasana kelompok (skor tercapai 95,7), kriteria tinggi, unsur ketaatan kelompok (skor 91), kriteria tinggi. dan unsur maksud tersembunyi (skor 95) kategori tinggi. Untuk menjaga kesinambungan kegiatan kelompok, maka peran pembina kelompok tani nelayan (PPL) agar lebih intensif.

\section{UCAPAN TERIMA KASIH}

Pada kesempatan ini, penulis ingin menyampaikan ucapan terima kasih dan penghargaan yang setinggi-tinggi kepada berbagai pihak yang telah membantu dan mendukung kegiatan penelitian ini. Ucapan terima kasih dan penghargaan disampaikan kepada pihak antara lain: 1) Direktorat Penelitian dan Pengabdian Kepada Masyarakat DIKTI, Jakarta yang telah bersedia mendanai penelitian ini, 2) Ketua Lembaga Penelitian dan Pengabdian Kepada Masyarakat Universitas Mulawarman, dan 3) Pihak Kecamatan Bontang Utara Kota Bontang serta Dinas Pertanian, Perikanan dan Peternakan Kota Bontang.

\section{DAFTAR PUSTAKA}

Badan Pusat Statistik. 2014. Bontang Dalam Angka. Badan Pusat Statistik Bontang. 


\section{Agriekonomika, ISSN 2301-9948

Disperta Kota Bontang. 2014. Laporan Tahunan Perikanan, Kelautan dan Pertanian Bontang. Dinas Perikanan, Kelautan dan Pertanian Bontang. Kota Bontang.

Djoni dan Maulana, F.A. 2009. Hubungan Antara Dinamika Kelompok Dengan Tanggap Adopsi Inovasi Budidaya Salak Pondoh. Jurnal Pembangunan Pedesaan 9(1): 17 - 24

Falo, M. 2015. Kajian Dinamika Kelompok Tani Ternak Sapi Potong di Kelompok Tani Nekmese Desa Manusasi Kecamatan Miomaffo Barat. Jurnal Agribisnis Lahan Kering 1(1): $15-18$

Hernanto dan Swastika. 2011. Penguatan Kelompok Tani: Langkah Awal Peningkatan Kesejahteraan Petani. Jurnal Analisis Kebijakan Pertanian 9(4): $371-390$

Ibrahim dan Tarik, J. 2002. Sosiologi Pedesaan. Universitas Muhammadiyah Malang.

Mugi, L. 2011. Dinamika Kelompok dan Kemandirian Anggota Kelompok Tani dalam Berusahatani di Kecamatan Poncowarno Kabupaten Kabumen Provinsi Jawa Tengah. Tesis. Program Pascasarjana Universitas Sebelas Maret, Surakarta.

Slamet, M. 2001. Paradigma Penyuluhan Pertanian dalam Era Otonomi Daerah. Makalah disampaikan pada Pelatihan Penyuluhan Pertanian di Universitas Andalas.

Sumarto dan Hetifah. 2003. Inovasi, Partisipasi dan Good Governance. Yayasan Obor. Indonesia.

Wijayanti, L dan Ihsannudin. 2013. Strategi Peningkatan Kesejahteraan Masyarakat Nelayan Kecamatan Pademawu Kabupaten Pamekasan. Agriekonomika 2(2): 149 -162 